msh-mss Mathématiques et sciences humaines

144 | Hiver 1998

Varia

\title{
Taux de dispersion des valeurs propres en ACP, AC et ACM
}

Dispersion rate of eigenvalues in PCA, CA and MCA

Jean-Luc Durand

\section{CpenEdition}

1 Journals

Édition électronique

URL : http://journals.openedition.org/msh/2783

DOI : $10.4000 / \mathrm{msh} .2783$

ISSN : 1950-6821

Éditeur

Centre d'analyse et de mathématique sociales de l'EHESS

Édition imprimée

Date de publication : 1 décembre 1998

ISSN : 0987-6936

Référence électronique

Jean-Luc Durand, «Taux de dispersion des valeurs propres en ACP, AC et ACM », Mathématiques et sciences humaines [En ligne], 144 | Hiver 1998, mis en ligne le 10 février 2006, consulté le 23 juillet 2020. URL : http://journals.openedition.org/msh/2783 ; DOI : https://doi.org/10.4000/msh.2783

Ce document a été généré automatiquement le 23 juillet 2020.

(c) École des hautes études en sciences sociales 


\title{
Taux de dispersion des valeurs propres en ACP, AC et ACM
}

\author{
Dispersion rate of eigenvalues in PCA, CA and MCA
}

\author{
Jean-Luc Durand
}

\section{RÉSUMÉS}

Nous définissons le taux quadratique de concentration d'une mesure positive, ou taux quadratique de dispersion des valeurs de sa densité élémentaire. Appliqué aux valeurs propres d'un nuage de points dans un espace euclidien, ce taux s'interprète géométriquement comme un indice de non-sphéricité du nuage, rendant compte de sa capacité à être bien résumé par le(s) premier(s) axe(s). Nous donnons, en les commentant, les expressions de la variance corrigée et du taux de dispersion des valeurs propres pour les méthodes les plus usuelles d'analyse géométrique des données : analyse en composantes principales (ACP pondérée, simple et normée), analyse des correspondances (AC) et analyse des correspondances multiples (ACM). Ces relations montrent notamment qu'en ACP normée et en ACM l'intensité moyenne des liaisons binaires entre les variables s'exprime géométriquement par la non-sphéricité des nuages de points.

We define the quadratic concentration rate of a positive mesure, or quadratic dispersion rate of the values of its elementary density. When applied on the eigenvalues of a cloud of points in an Euclidean space, this rate is geometrically interpreted as an index of non-sphericity of the cloud, which accounts for its capacity to be well summarized by the first axis or axes. We provide and comment upon the expressions of corrected variance and dispersion rate of eigenvalues for the most usual methods of geometric data analysis : principal component analysis (weighted PCA, simple and standard) correspondence analysis (CA) and multiple correspondence analysis (MCA). These relationships particularly show that in standard PCA and in MCA, the average intensity of 
binary relations between variables is geometrically expressed by the non-sphericity of clouds of points.

INDEX

Thèmes : données (analyse des), géométrie, linéaire (algèbre), mesure - mesurage 